Copyright (C) The Author(s), 2022. Published by Cambridge University Press on behalf of The American Society of International Law.

doi:10.1017/amp.2021.168

\title{
FOREWORD
}

\section{Reconceiving International Law: Creativity in Times of Crisis}

The 115th Annual Meeting convened virtually on March 24-26, 2021, amid the continuing coronavirus pandemic, now in its second year. The Annual Meeting theme, "Reconceiving International Law: Creativity in Times of Crisis," presented an opportunity to step back from the daily barrage of bad news - from the pandemic to the accelerating effects of climate change, to the continued erosion of the rule of law around the world - and to consider how international law and legal institutions might be reconceived to offer innovative solutions for what often seem insuperable problems. The organizers also used this opportunity to think creatively about the shape and structure of the Annual Meeting itself as a laboratory for thinking about the future of the international system.

In designing this second virtual meeting, the Annual Meeting Committee sought once again to offer our worldwide audience a rich and vibrant experience. Participants had the opportunity to engage with thought leaders in international law and related disciplines through more than fifty substantive sessions and six thematic tracks, including a full array of lectures, keynotes, plenary sessions, and governance meetings, as well as special interactive sessions created expressly for the virtual meeting.

The organizers made a number of accommodations to the virtual format, as they had with our first virtual meeting - for example, limiting substantive panels to a single hour with more frequent breaks to minimize viewer fatigue; pre-recording some sessions to allow participation by panelists in different time zones, and shifting some plenaries to earlier in the day. As it was not possible to gather the membership in person for the Annual General Meeting and other portions of the Assembly, the leadership elections were conducted by means of an online ballot sent to all members in good standing, and the various ceremonial elements of the Assembly, including memorials, honors, and awards, took place during a live Opening Plenary and a pre-recorded virtual presentation of honors and awards.

The meeting also offered participants a variety of interactive sessions designed expressly for the virtual platform, including social, networking, and career development activities - and even nine wellness breaks (offering Tai Chi, meditation, and origami workshops) throughout the conference to help ward off "Zoom fatigue." A menu of professional development activities included small group mentoring sessions connecting students and new professionals with leading scholars and practitioners, and "Ask Me Anything" sessions with leaders in the field providing career advice and commentary on international legal issues. Many of the Society's thirty-four Interest Groups took advantage of the opportunity to host meetings and discussions, and a "virtual expo hall" enabled conferees to explore the information and resources presented by our sponsors and exhibitors. Additionally, each of the substantive sessions was followed by a "Continue the Conversation" feature, which allowed attendees to engage directly with presenters on the topics of the session, creating a virtual hallway to replicate the physical space where so many valuable conversations take place.

The response of the international law community was overwhelming, and registration exceeded the record we had set in 2020. Attendees included members and guests from around the world who 
had never attended an Annual Meeting before. In addition, conferees who ordinarily would have had to choose among the many concurrent activities were able to view as many sessions as they wished, either as they were happening or on-demand. All the sessions remained available exclusively to conferees for sixty days following the meeting, and then were made accessible to the public as part of the Society's open access video library.

During the two weeks preceding the Annual Meeting, the Society hosted four online "Global Engagement" panels, organized in collaboration with leading regional societies in Africa, Asia, Europe, and Latin America. The sessions were scheduled at times that would be optimal for regional participants, and they were focused on topics related to the Annual Meeting theme that a regional audience would find of particular interest. The entire series was made available to the public without charge as a way of introducing both members and non-members to the online meeting platform and encouraging them to register.

The formal meeting began on the morning of Wednesday, March 24, with an Opening Session convened by President Catherine Amirfar. She delivered brief remarks and expressed her appreciation to the co-chairs and members of the Annual Meeting Committee. She also announced that the co-chairs of the 2022 Annual Meeting would be Rachel López, Kish Parella, and Patrick Pearsall. She then acknowledged the members who had attained emeritus status and asked for a moment of silence in memory of members who had died since the last Annual Meeting. The keynote address was given by the Rt. Hon. David Miliband, former Foreign Secretary of the United Kingdom and President and CEO of the International Rescue Committee. His remarks were followed by a Presidents' Roundtable moderated by President Amirfar and featuring four of her distinguished predecessors as President of the Society_-José Alvarez, Edith Brown Weiss, Lucinda A. Low, and Sean D. Murphy.

Another highlight of the first day was the presentation of the 2021 Manley O. Hudson Medal to Professor Bernard H. Oxman (ASIL Academic Partner University of Miami School of Law). After the formal presentation, Paul Reichler offered brief remarks on behalf of the event sponsor, ASIL Law Firm Partner Foley Hoag LLP. Professor Oxman then participated in a conversation with Professor Lori Fisler Damrosch (ASIL Academic Partner Columbia Law School), who served as President of the Society from 2014-2016.

The Wednesday sessions concluded with the presentation of the 2021 Goler T. Butcher Medal to Louise Arbour, the former UN High Commissioner for Human Rights. The program featured a conversation between Mme. Arbour and 2009 Butcher Medal recipient Mónica Pinto (University of Buenos Aires School of Law).

The Thursday sessions began with the 23rd annual Grotius Lecture, presented in cooperation with American University Washington College of Law. The lecture was delivered by Yves Daudet (University Paris I Panthéon-Sorbonne), the President of the Curatorium of the Hague Academy. His remarks were titled, "Never Let a Good Crisis Go to Waste! Can International Law Seize the Advantage?" Distinguished discussant Hannah Buxbaum (ASIL Academic Partner Indiana University Maurer School of Law) delivered the response.

The Thursday afternoon plenary featured keynote remarks by Dr. Tedros Adhanom Ghebreyesus, the Director General of the World Health Organization, on "Law, Equity and Global Public Health." His remarks were followed by a virtual ceremony recognizing the recipients of the Society's 2021 honors and awards.

Also on Thursday, the Women in International Law Interest Group (WILIG) presented the 2021 Prominent Woman in International Law Award to former ASIL Honorary President Gabrielle Kirk McDonald. Following the presentation, she participated in an informal conversation with WILIG co-chairs Nienke Grossman and Milena Sterio.

The Friday sessions began with the presentation of the Honorary Member Award to H.E. Abdulqawi Ahmed Yusuf of the International Court of Justice. Following the presentation, 
Judge Yusuf offered brief remarks and then engaged in a keynote conversation with Patrícia Galvão Teles of the International Law Commission.

Other programs of note included the Sixth Annual Detlev F. Vagts Roundtable on Transnational Law, convened by Gian Luca Burci (ASIL Academic Partner Graduate Institute Geneva), on "Pandemic Vaccines: Market Products or Global Public Goods?" and the Ninth Annual Charles N. Brower Lecture on International Dispute Resolution, which was delivered by Lucy Reed on "Crisis Cases: Not Reconceiving International Dispute Resolution."

The closing plenary, sponsored by the Asser Institute for International and European Law, the Embassy of the Netherlands in the United States, and the Municipality of The Hague, featured opening remarks by Hon. Jan van Zanen, the Mayor of the Municipality of the Hague, followed by a roundtable discussion on "Reconceptualizing International Law's Role in the Governance of AI: Autonomous Weapons as a Case Study."

At the conclusion of the session, President Amirfar offered a virtual toast featuring the signature cocktail of the 2021 Annual Meeting - the "Paquete Habana," after the landmark 1900 decision by the U.S. Supreme Court holding that "international law is part of our law" and the capture of coastal fishing vessels as prizes of war violated customary international law. As the President gaveled the 115th Annual Meeting to a close, the screen filled with a photomontage of hundreds of Annual Meeting attendees, representing the ASIL community in all its strength, resilience, and diversity.

The success of this second virtual meeting was due to the creativity, hard work, and commitment of many people, including Annual Meeting co-chairs Simon Batifort, Christie Edwards, and Darin Johnson, and all the members of the Annual Meeting Committee; the Society's Technology Committee, comprising Rebecca Hamilton, Corina Gugler, and Anupam Chander; our meeting planner, Eden Capuano, and her team at Voila! Inc.; the team at Silo, who developed the virtual platform for the meeting; and most of all, to deputy executive director Wes Rist and the extraordinary staff of the Society.

Finally, thanks are due to Erin Lovall, the editor of these Proceedings, and to the speakers, sponsors, partners, exhibitors, and registrants who collaborated with us in creating a truly remarkable Annual Meeting experience.

Mark DaVid Agrast

Executive Director

March 2021

Washington, DC 